\title{
PALESTINIAN PERSPECTIVES ON FOREIGN AID
}

\author{
Raed Awashreh * ${ }^{*} \bowtie$ \\ ${ }^{* 1}$ Independent Researcher, Palestinian Territory, Palestine
}

DOI: https://doi.org/10.29121/granthaalayah.v8.i6.2020.539

Article Type: Research Article

Article Citation: Raed Awashreh. (2020). PALESTINIAN PERSPECTIVES ON FOREIGN AID. International Journal of Research GRANTHAALAYAH, 8(6), 236-251. https://doi.org/10.29121/granthaa layah.v8.i6.2020.539

Received Date: 10 May 2020

Accepted Date: 30 June 2020

Keywords:

Palestinian NGOs

Israel Occupation

Foreign Aid

Political Aid

\section{ABSTRACT}

Although Palestinian non-government organizations (NGOs) are hiring some employees and supply money to local market, this article argues that NGOs are moving within the political place of donor's agenda meaning western governments' agenda. The historical trends in funding NGOs in the occupied Palestinian territory essentially aim at ending the Palestinian struggle against occupation and encouraging Palestinian masses and institutions to de-politize their agendas and forsake their national goals. In other words, foreign aid has no problem with the continuation of Israeli occupation or that Palestinians never have a (sovereign) state. All indications show that what paramount to donors since the start of peace process is keeping Israel safe and maintaining a limited Palestinian authority with no capacity to pose a threat against Israel. From the Palestinians side, disagreement on foreign aid among them based on funds source UN fund is acceptable, other different between USAID and European funds, other differentiate between government and nongovernmental funds.

\section{INTRODUCTION}

Several local NGOs had been serving Palestinians since 1948 and later the number has increased due needs that raises because of the occupation (Governance \& Social Development Resource Centre, 2010). NGOs uses the slogan supporting the Palestinian steadfastness on their lands, however, during eighties and nineties up forward, a lot start questioning the role of Palestinian NGOs in defend steadfastness and advancing national goals (Hamdan, 2010). it is important to explore the extent to which NGOs adhere to them and the level of their commitment to their advancement. At the outset, it is important to stress that the Palestinian goals within the context of this research refer to those goals determined by the Palestinians themselves rather than by Israel or Western governments. To people, they represent the dreams to accomplish as the majority of Palestinians believe that the two-state solution is a more suitable solution for the Israeli- Palestinian conflict than the bi-national or Islamic state alternatives (Jerusalem Media \& Communication Centre, 2011).

This article argues that Palestinian NGOs are moving within the political position of donors' agendas which are in this case the Western governments' agenda. Prior to Madrid and Oslo, donors, mainly Europeans, encouraged Palestinians to accept the two-state solutions but today, their agendas seem to be centered on maintaining the Israeli occupation and pushing the negotiations in the direction of pro-Israeli solution even if it means a departure from the long held two-state solution. It argues that historical trends in funding NGOs in the oPt essentially aim at ending the Palestinian struggle against occupation, and encouraging Palestinian masses and institutions to de-politize their

(C) 2020 The Author(s). This is an open access article distributed under the terms of the Creative Commons Attribution License, which permits unrestricted use, distribution, and reproduction in any medium, provided the original author and source are credited. 
Palestinian Perspectives on Foreign Aid

agendas, and forsake their national goals. In other words, foreign aid has no problem with the continuation of Israeli occupation or that Palestinians never have a (sovereign) state. All indicators show that what paramount to donors since the start of peace process is the security of Israel and the maintenance of a limited Palestinian authority with no capacity to pose a threat against Israel.

This paper contains four major sections. Section two represents literature review and shows that Camp David Accord between Egypt and Israel has set the framework for foreign aid to Palestinians NGOs. Section three explain the research methods that have used to develop this paper. Section four represents the results and the discussion over field findings on NGO funding. In addition, it presents the major trends and changes in NGO funding over the past few decades, and last followed by a brief conclusion of the overview of NGO funding.

\section{AID POLITICAL FRAMEWORK}

The flow of foreign aid to oPt correlated with Palestinian recognition of Israel's right for existence over the occupied Palestine in 1948 when in 1974, the PLO launched a political initiative for the creation of a national authority over any land they liberate or Israel withdraws from (Khaldi, 2008). In 1978 foreign funds started to flow to oPt in the aftermath of Camp David Accord between Egypt and Israeli was signed in the same year.

It is widely believed the process of NGO-zation (i.e. converting Palestinian mass organizations into NGOs) had started in Camp David era. The first generation of Palestinian NGOs appeared in this period due to multiple factors interacting simultaneously:

- Some educated Palestinians and university graduates want to help the community via NGOs (Samara, 2001),

- An understanding between the USA and Israel to allow the occupied Palestinians to breath and improve their economic situation as a detour from the national struggle (Nakhleh, 1989; Samara, 2001; Qassoum, 2004),

- Inflow of funds to the oPt via international organizations and government agencies (Nakhleh, 1989),

- Aid for civilian and humanitarian purposes benefited the Israeli economy because of the dependency of Palestinian economy on the occupation (Samara, 2000),

- Fateh encouraged Palestinians in the oPt to create their associations as a way of steadfastness and selfhelp.

The first wave of donor funds was directed to relief through several American and INGOs and chapters (Nakhleh, 1989) to reduce the damage of occupation. It was followed by a wave of university scholarships in order to create a group of co-opted educated individuals for the promotion of peace and non-violent struggle strategies (Qassoum, 2004). On one hand, the US understood that poverty and refugee tents under military occupation do not leave open choices other than carrying guns to fight occupation, on the other hands, rich families were building houses and pursuing their personal interests, both of which are not the right motive behind engaging in national struggle.

Some activists reject the correlation between NGOs, Camp David and available funding reflecting that NGOs (a) rejected the agreement and the notion of limited autonomy it proposed to Palestinians, and (b) Palestinian political factions encouraged NGO creation push community involvement forward as a way of resisting the occupation. What is missing here, the catalyst effect the historical changes had on NGO creation and the role played by the Joint Palestinian-Jordanian Committee. Such view also neglects donors and NGOs' focus on service delivery did nothing to promote national goals (Qassoum, 2004; Samara, 2001). Worse, NGOs hardily acknowledge the fact that Oslo Accords generated funding opportunities in the 1990s all based on the incarnation of principles of Camp David Accord. It can also be said that NGOs were prepared by donors to play a role in forming the PA (Abdaulhadi, 2004). Many NGO figures experts took part in the negotiation process (through participation in technical committees) or joined the many PA institutions. Or that the three sectors; PA, private sector, and NGOs, in fact cooperate for the depoliticization of Palestinian society. The overarching objective is to restructure the geographical sphere in line with the Israeli interest of sustained control of oPt and subordination of its economy (Hamdan, 2010).

The issue of foreign funding to oPt is viewed from different perspectives. A very popular perspective among Palestinian NGOs looks at aid as a legal right for an occupied nation provided for by various UN decisions and declarations (UN General Assembly Resolution NO 128/41 cited in Hamdan, 2010) pertinent to the Palestinian question (Qazzaz cited in PJW, 2008). The second perspective refers to guilty conscience in which donors on behalf 
of their Western governments are trying to compensate Palestinians for bringing the Israeli occupation and causing a lot of sufferings. The third view believes that aid is an obligation resulting from the negotiation process since Madrid and Oslo Accords.

The 'legal' perspective assumes an implausible scenario of foreign aid being enforced by the international law while the 'guilty' and 'compensatory' perspectives depoliticize aid and present it in more positive terms. Nevertheless, all three perspectives help in understanding why financial support is usually accompanied, or driven, by donors' agendas and to the political, social and economic changes that foreign funding brings in the oPt. Two alternative views link foreign funding to Neo-liberal agenda and the restructure the oPt through funding. In other words, foreign aid strives politically, ideologically and culturally to transform the Palestinian society to become more receptive of and indefinitely tolerate the Israeli occupation (Samara, 2001; Qassoum, 2004; Hamdan, 2010; Sebieh, 2011). A benign version of this hypothesis sees donor funding working to maintain peace and non-violence as well as support the peace process through ensuring that PA remains a 'non-viable' entity without international financial assistance.

\section{RESEARCH METHODS}

To investigate on this issue, a combination of qualitative and quantitative methodology has adopted, using primary and secondary data over NGOs in the West Bank to build a theory from the field. Five main data collection instruments uses here: (1) a structured six-page survey was distributed to a pre-selected sample of forty organizations. 40 adult respondents selected from NGOs across the West Bank. A perception survey on the opinions and positions of $100 \mathrm{NGO}$ staff members carried out using a one-page structured survey. (2) Face to face interviews with 53 interviewees representing a wide range of NGOs, relevant PA institutions, local organizations, donors, and civil society activists and experts. Each semi-structure interview took 1/2 -2 hours to complete, especially if the interviewee has many professional capacities or formal roles in the community (i.e. university professors, mayors, and NGO board members, etc. (3) Three focus group discussions for NGOs members and activists in the West Bank. The researcher called selected organizations to explain the purpose and nature of the research and the issues to be addressed in the focus groups, and agree on suitable day, time, place, and other logistical issues ${ }^{1}$. The three- hour focus groups were held: one in district of Tulkarem, El-Kafreyat rural areas, and two more held in the town of Beit Rima and Al-Amari Refugee camp in Ramallah district. The second focus group in Ramallah had participants selected from refugee camps in Ramallah, Jerusalem and Jericho districts. (4) Three case studies were undertaken on a number of urban and rural-based CBOs and NGOs in the target districts. The case studies were developed through interviews and additional focus groups discussions. The target localities were chosen because of the researcher's familiarity with their social contexts and for their physical proximity conducive to frequent field visits for data collection. (5) In addition, six exploratory meetings with key informants and experts were held to solicit their views and ideas on the issues under investigation. They are located in the city of Ramallah and approached on their expertise and ability of cooperation.

\section{RESULTS AND DISCUSSION}

The data below constructed from the field supported by secondary data sources. Here are the results and discussion over findings:

\subsection{SOURCE OF FUNDING}

During personal interviews and the NGOs organizational survey, the study investigated NGOs financial status through a series of questions without asking respondents to specify the amount of received donor funding. In this section, I will first present the financial findings of this study in comparison to results already documented in the literature on Palestinian NGOs. These studies indicated that since 1993 the European states share by far been the

${ }^{1}$ Sometimes, I spent the entire day was spent in one community doing interviewing and talking to the residents as well as to gain people's trust prior to data collection. Some locations preferred meeting in the afternoon or in weekends and demanded that I make arrangement for their transport. 
largest aid contributor to the PA and NGOs in the oPt. "The Arab League states have also been substantial donors, notably through budgetary support to the Palestinian National Authority (PA) during the [ second] intifada" (More,2005, p.982). Today, it is estimated that 78.3\% total NGOs fund comes from external sources (DeVoir \& Tartir 2009, p. 32).

Table 1 below shows that $50 \%$ of NGOs in the study sample has received fund from the European Commission and about $37.5 \%$ receive support from other European countries. The findings show that $87.5 \%$ of the sample has received funds from European origins ranked as the first three important sources for the NGOs. By comparison, about $50 \%$ of respondent NGOs have access to American and Canadian funds but very few actually rank them as the highest contributors. In other words, USA does provide funding yet the Palestinian NGOs do not consider that as their main funding source. This may reflect many factors: (a) the actual fluctuation in USA funding, (b) NGOs find it difficult to accept US pre-award conditions, and (c) NGOs inability to satisfy the very complex contractual obligations attached to US funding.

Table 1: Source of Foreign Aid to NGOs by No of NGOs \& Donor Ranking

\begin{tabular}{|l|c|c|c|c|c|c|c|c|}
\hline \multirow{2}{*}{ Funding Source /Region } & \multicolumn{6}{|c|}{ Respondents } & \multicolumn{6}{|c|}{ Donor's Ranking } \\
\cline { 2 - 9 } & Total & $\%$ & 1 & 2 & 3 & 4 & 5 & 6 \\
\hline Arab countries & 15 & $37.5 \%$ & 4 & 4 & 5 & 2 & & \\
\hline European Commission & 20 & $50 \%$ & 9 & 8 & 3 & & & \\
\hline Other European countries & 15 & $37.5 \%$ & 4 & 6 & 4 & 1 & & \\
\hline USA and Canada & 20 & $50 \%$ & 3 & 7 & 6 & 4 & & \\
\hline Islamic, non-Arab countries & 5 & $12.5 \%$ & 2 & 1 & 2 & & & \\
\hline Southern American countries & 2 & $5 \%$ & & 2 & & & & \\
\hline Other Asian countries & 5 & $12.5 \%$ & 5 & & & & & \\
\hline Foreign governmental agencies & 18 & $45 \%$ & 4 & 10 & 1 & 1 & 2 & \\
\hline International NGOs & 30 & $75 \%$ & 23 & 4 & 2 & 1 & & \\
\hline Local sources & 27 & $67.5 \%$ & 15 & 5 & 2 & 4 & - & 1 \\
\hline
\end{tabular}

Survey sample: 40 NGOs. The "Respondents" column represents the total number of NGOs that answered each question regardless of their ranking of the source of donation.

Furthermore, $75 \%$ of the sample NGOs reported funding from INGO including UN agencies. About $45 \%$ of NGOs had financial assistance from foreign governmental agencies compared to 37\% from Arab countries. Asian and Islamic countries combined occupied the fifth place as reported by $25 \%$ of sample NGOs (only 10 organizations). In terms of local funding, Table 2 shows that it is not an important source to the respondent NGOs although a small percentage does rely on local contribution as a primary source of funding.

Table 2: Source of Local Funding to NGOs

\begin{tabular}{|l|c|c|c|c|c|c|c|c|}
\hline \multirow{2}{*}{ Funding Source } & No of Respondent NGOs & \multicolumn{5}{|c|}{ Donor's Ranking } \\
\cline { 2 - 8 } & Total & $\%$ & 1 & 2 & 3 & 4 & 5 & 6 \\
\hline National institutions (PA, PLO) & 22 & $55 \%$ & 1 & 9 & 10 & 1 & - & 1 \\
\hline Private sector & 21 & $52.5 \%$ & 1 & 7 & 3 & 6 & 4 & - \\
\hline Individuals from Local \& Diaspora communities & 25 & $62.5 \%$ & 6 & 7 & 5 & 4 & 2 & 1 \\
\hline Revenue from services and membership & 10 & $25 \%$ & & & & & & \\
\hline
\end{tabular}

Survey sample: 40 NGOs. Total respondents in indicates the number of NGOs that answered that particular question on funding sources. Donor's ranking indicates the number of NGOs that ranking each donor as the $1^{\text {st }}, 2^{\text {nd }}$, $3^{\text {rd }}$, etc. with regard to each funding source.

A breakdown of local funding sources shows that the Palestinian private sector contributes to supporting some activities of $52 \%$ of NGOs, although it is not the major source. The private sector sometimes offers in-kind or cash donation upon NGOs request or as part of the newly emerging 'corporate social responsibility' programs as is the case with few banks, telecommunication firms and insurance companies. It is very interesting to note that local communities and Palestinian expatriates channel funds to $62 \%$ of NGOs that see such fund as important source in terms of frequency rather than size. In addition, very few NGOs reported benefiting from PA periodic support to help 
Raed Awashreh

with the salaries, rent and other costs while others reported additional funding from services revenues and membership fees.

\subsection{ACCEPTABILITY OF AND ALTERNATIVES TO FOREIGN AID}

Palestinian NGOs can be judged as 'good' or 'bad' as a result of receiving funding from 'good' or 'bad' donors. Donors are judged from two considerations: (1) their position from Palestinian national rights and (2) their interference in determining public priorities.

Foreign aid is widely acknowledged as a 'double-edged sword' (Kulick, 2007). On one side, it helps boost the local economy, directly and indirectly. Although part of NGOs funds is wasted on hotels and publications, it is money channeled into the Palestinian market in the form of workers' salaries, and contracts with service sector (GI., conversation, 2 December). But aid has many negative manifestations that outweigh the positives: distortion of local salaries, the creation of new elite of NGO careerists, co-optation of middle class intelligentsia, and the substitution of voluntarism by paid employment, to mention but a few (Samara, 2001; Qassoum, 2004; Hamoudah, 2011). Almost in every occasion, NGO leaders claim their organizations reject conditional funds and accuse others of following foreign and donor- driven agenda, regardless if the latter's funding originate from governmental or nongovernmental agencies (SA., interview, 1 February; A.K., interview, 17 March; A.J., interview, 27 March; ZN., interview, 15 February; KB., interview, 15 March; E.A., interview, 7 April).

Apparently, the study findings revealed lack of agreement among NGO leaders on the acceptability or otherwise of donor funding. To them, all funding comes with various forms of conditions even donors' support to the PA, but there are funds more acceptable than others such as support given by Arab and Islamic countries and solidarity groups in Southern America and Europe (Hamdan, 2010) although such support is much more limited than that provided by Western sources (E.A., interview, 7 April; KB., interview, 15 March; ZN., interview, 15 February). Arab and Islamic funds are 'cleaner' because they are not attached to social transformation and de-politicization agendas espoused by the neo-liberal Western countries and most international donor agencies. Another category is labelled 'ok donors' that support Palestinian NGOs directly managed by an intermediate Palestinian organization i.e. the Welfare Association (Hamdan, 2010).

Mirroring disagreement on the ultimate objective of foreign aid, Palestinian NGOs differ on whether or not the Palestinians, including PA and NGOs, should accept foreign funding. On one hand, some NGOs favour boycotting foreign aid because donors' conditions and priorities are irrelevant to the actual needs of the Palestinian public (E.A., interview, 7 April). This is the view mostly expressed by traditional, charitable associations such as Ena'ash El-Usra in Ramallah and El-Bir El-khayerieh in Nablus that depend entirely on local and Arab resources instead of foreign aid (EA, interview, 7 April; YH, communication, 3 February).

On the other hand, the majority of NGO leaders, managers, and staff oppose the boycott on the ground that it is a legitimate assistance used to serve the Palestinian public and without which NGOs will be forced to shut down their programs and services (TI., interview, 15 march; I.B., interview, 16 February; M.B., interview, 30 March). Only a few interviewees stated that foreign political goals, or foreign agendas, do not always go against the public or national agenda (GI., conversation, 2 December) or went farther to deny that humanitarian assistance conceals foreign political interests and goals (ET., interview, 15 March).

The common view among the political parties and the interviewed NGO leaders stresses the importance of foreign funding for their organizations and the oPt generally (Jabber, 2011). Despite a tendency to agree on the political motivation, there was less agreement on the negative impact of aid and the necessity to boycott it for both reasons (i.e. political motivation and negative impact). In fact, the position of this or that individual from foreign aid depends on where s/he stands from the aid map and the personal benefit derived from this aid. Those who are generally in favour of continued foreign assistance are top level managers interested in maintaining NGOs services and staff. Some argued that neither NGOs nor PA are capable of survival without foreign aid so governmental officials and NGOs cannot reject foreign aid when the PA is the biggest 'NGO' in the donor funding business (KB., interview, 15 March; ER., interview, 5 December; Hamodah, 2010; Hamadan, 2010). Unlike donor-dependent NGOs, political 
Palestinian Perspectives on Foreign Aid

parties favour a boycott because they do not seem to be directly ${ }^{2}$ affected by foreign aid since their budgets, and the PLO budget, are determined by the PA budget itself (Jabber, 2011).

Regardless of this major difference, the main objection is directed to funding practices rather than to funding per se. Palestinian political and NGO leaderships direct their criticism to the strings attached to funding and decisions-making in fund management. NGOs leaders feel there is an urgent need for re-structuring donor-NGO relations in a way that enables the Palestinian NGOs, not donors, to determine priorities, project and actual interventions as an alternative to the current methods in which donors use their funding power as a leverage for setting NGOs agendas and plans (JA., interview, 31 March; Kh., interview, 26 April; KB., interview, 15 March; M.B., interview, 30 March).

A third position is slightly pragmatic in the distinction it makes between donors. This view is more in favour of receiving funds from solidarity groups but not from source classified as 'conditional donor funding' such as the USAID (KB., interview, 15 March; and M.B., interview, 30 March,). NGOs boycott, or claim to boycott USA fund on the ground of the anti-terrorism certificate, vetting, and many other procedures that treat Palestinian NGOs as supportive of 'terrorists'. Therefore, many NGOs under the PNGO umbrella and other left-leaning NGOs label US funding as bribery (AL., interview, 15 December). In comparison, Fateh affiliated NGOs accept funds and all of its conditions dictated by the US and many other donor agencies or international organizations (SA., interview, 1 February). The left-leaning NGOs are more content with dependence on pro-Palestinian 'solidarity funds' from European countries, the UN and other international agencies (Survey and interview results). As an extension of this logic, Palestinian NGOs are good or bad depending on how good or bad are their donors in the public's eyes.

The focus groups and one-to-one interviews echoed all of these sentiments.

The absolute rejectionist stance argues that foreign aid is harmful and unacceptable as a substitute for 'national freedom' (NR, interview, $21 \mathrm{March}$ ). New Palestinian generations are capable of living on their own "just like our parents lived without foreign aid" (SM., interview, 18 December). Some NGOs called for a unified position among all NGOs to boycott foreign aid in preference for promotion of 'inter-Palestinian solidarity' and reliance on local resources and social capital. As the interviews progressed, some changed their opinions from utter rejection of funding more towards reforming fund management practices from both donors and recipient NGOs (SM., interview 18 December; NR., interview, 21 March). Only a few maintained convictions in local resources shift although they admitted that such resources are meagre and their organizations have no strategic vision and plans to increase local funding or come up with sustainable alternatives to foreign aid. Thus the only substitute for blanket acceptance of funding seems to rest on a combination of three strategies: a) NGOs making a distinction between good versus bad funding (KB., interview, 15 March; M.B., interview, 30 March), b) NGOs shifting to Arab or Palestinian funding such as the funds managed by the Welfare Association (KB., interview, 15 March; Hamdan, 2010), and c) NGOs building an egg nest of funding (i.e. endowments) to ensure flexibility and continuity in case donors' interests contradict the NGO's or that the donor interferes in NGO agenda and programs (KB., interview, 15 March; M.H., interview, 20 February).

From all of the above, it seems that foreign funding is a matter not only of personal perspective but also of life style too. To say no to foreign funding implies that Palestinians need to forsake their style of consumption (cars, private schooling, clothing, food, travelling, mobile phones and all luxuries). Saying yes means moving along with the 'globalized' way of life style which is possible if there is will, trust, beliefs and awareness. To quote NR, "all Palestinian institutions and groups must collectively cut foreign aid. Not only few organizations, but all of us should do that when just a few do that, nothing will change" (NR., interview, 12 March). NR himself struggles with his position towards foreign aid. He faces a dilemma that many NGO leaders and mayors face:

"As a university professor I used to freely criticize and speak out against foreign aid. As a mayor, not any more. I need funds to do some projects to the town. People look at and watch what I have done so far for them. The town has many needs, and my job is to secure funds. European or American funds are all the same. USA agencies are working with us on organizational - institutional development and infrastructure projects too" (NR., interview, 12 March).

\footnotetext{
${ }^{2}$ Palestinian political parties do receive an annual budget from the PA as they used to receive support from the PLO prior to Oslo Accords. Some political cadres appear on the payroll of various ministries even when they are actually staff of PLO-affiliated agencies or working full time for political parties.
} 
In other words, it is far easier to condemn than suggest 'appropriate' alternatives to the potentially damaging foreign aid given to mitigate public resistance and the occupation's negative impact on the occupied people. Like other NGO leaders, the stance taken by mayors and public officials depend on the ability of their institutions to serve the public but they also want to showcase accomplishments and fulfill the promises made during election campaigns. What is missing now is people's internal solidarity and social capital allowing dependence on limited available resources (KB, interview, 15 March; SM., interview, 18 December). To call for a 'simpler life' may seem like a call for a relapse to the 'dark age' without the advanced technology in the 'global village' era. But if this is the public's choice, others should respect it, including the NGOs and donors.

In theory, NGOs can negotiate with donors the priorities and strategies of their cooperation which implies that NGOs can be design makers at the same footing with their donors. In reality, NGOs leaders are less interested in, motivated, or have the power to force such a change because their personal and organizational agendas and interests are all at stake. Although NGOs leaders seem in agreement on the need to change foreign aid management, they shy away from the outright rejection of foreign funding. This objective has least chances of being achievable unless the Palestinians NGO develops certain types of homogeneity and a unified agenda for the third sector.

\subsection{CHANGES IN NGO FUNDING TRENDS}

It is an established truism that financial support to Palestinian NGOs is extended by foreign governments, international NGOs, Arab states, UN agencies, charities, and foundations and sometimes political parties and solidarity groups worldwide. In addition; there are local resources such as the PA, private companies, Zakat money, local donations, and Palestinian expatriate communities. About $62 \%$ of total funding to Palestinian NGOs comes through international NGOs and major donors in European Union, USA, UK, France, Spain, Switzerland delivered either and 38\% from governmental agencies (DeVoir \& Tartir, 2009). It is worth noting that since Oslo Accords, about 54\% of foreign aid to the Palestinian territories had come from European Union (Hamdan, 2010, p. 52).

Table 3 below reveals interesting variations in donors' attitude to the PA and Palestinian NGOs. Overall, there is a clear preference for channeling funding through the PA except when the PA falls out of the donors' favor. Overall, NGOs share, according to the above figures, has not exceeded $19.5 \%$ in its highest values in 2005 . This year marked the second national elections in the oPt since 1994: two rounds of local council elections, the presidential elections and the Legislative Council election in early 2006. In 2005, NGOs received almost three times the amount received in 2003-4 when NGO total funding decreased by 50\%, from 103 million in 2002 to a mere 57 million in 2004. The year 2006 also marked another period of increased PA funding and decreased donor support to NGOs. By 20083, NGOs funding slightly improved although PA support were at an unprecedented level. In comparison to 2005 level, NGOs received in 2008 only 40 million more than its share in 2005 while PA funding increased by more than 2.15 billion from the 2005 level.

Table 3: \% of Annual Increase in NGO funding of Total Foreign Aid to oPt

\begin{tabular}{|c|c|c|c|c|c|}
\hline Year & $\begin{array}{c}\text { Total Foreign Aid } \\
\text { to oPT in US\$ } \\
\text { Million }\end{array}$ & $\begin{array}{c}\text { No. of } \\
\text { Foreign Aid } \\
\text { NGOs }\end{array}$ & $\begin{array}{c}\text { \% of NGO funding of } \\
\text { Total Annual Foreign } \\
\text { Aid to oPt }\end{array}$ & $\begin{array}{c}\text { \% of Annual } \\
\text { Increase in Total } \\
\text { Foreign Aid to oPt }\end{array}$ & $\begin{array}{c}\text { \% of Annual Increase } \\
\text { in Total Foreign Aid } \\
\text { to NGOs }\end{array}$ \\
\hline 1999 & 516 & 48 & $9.30 \%$ & & $14.6 \%$ \\
\hline 2000 & 637 & 55 & $8.63 \%$ & $23.4 \%$ & $69.1 \%$ \\
\hline 2001 & 869 & 93 & $10.70 \%$ & $36.4 \%$ & $10.8 \%$ \\
\hline 2002 & 1616 & 103 & $6.37 \%$ & $86.0 \%$ & $-36.9 \%$ \\
\hline 2003 & 972 & 65 & $6.69 \%$ & $14.9 \%$ & $-12.3 \%$ \\
\hline 2004 & 1115 & 57 & $5.11 \%$ & $0.1 \%$ & $-10.1 \%$ \\
\hline 2005 & 1116 & 218 & $19.53 \%$ & $29.9 \%$ & $8.7 \%$ \\
\hline 2006 & 1450 & 196 & $13.52 \%$ & $29.4 \%$ & $21.1 \%$ \\
\hline 2007 & 1876 & 213 & $11.35 \%$ & $73.2 \%$ & \\
\hline 2008 & 3250 & 258 & $7.94 \%$ & & \\
\hline
\end{tabular}

${ }^{3}$ If the dollar decrease in value is taken into consideration, the actual value of 2008 funding is about 2.6 billion rather than 3.5 billion because the US dollar lost about $20 \%$ of its value between 2004-2008 while the PA budget is in Israeli Shekels. 
Palestinian Perspectives on Foreign Aid

\begin{tabular}{|c|c|c|c|c|c|}
\hline Total & 13417 & 1305 & Av: $9.73 \%$ & Av: $28.1 \%$ & Av: $38.6 \%$ \\
\hline
\end{tabular}

Source: (DeVoir \& Tartir, 2009)

The abundance of funds indicated in the above table may paint a distorted image. Firstly, funding fluctuates considerably in accordance with political developments or lack thereof. For example, most Western, nongovernmental agencies extended large-scale funding immediately after Madrid and Oslo Accord (HI., interview, 9 April). The USA, for example, had offered USD 3.3 billion since 1994, channeled through the PA, USA private organizations and firms operating directly in the oPt such as Chemonics, ANERA, Catholic Relief Services, CHF, IRD, and others (Nakhleh, 2011). After 2000, US funds dropped to the lowest level then increased slightly after 2004. In 2008, European funding comprised $70 \%$ of total NGO funding while the USA funding recorded only 5\% of funds which is a significant decrease from its 12\% in 1999 (DeVoir \& Tartir, 2009).

The current study also found many evidence of decreased NGO share of total oPt funding. Of the 40 organizations in the survey sample, 29 respondents identified and explained changes in NGOs funding trends in the past few years. 24 NGOs noticed a decrease in available funding and the other 5 organizations denied being affected by a funding cut. For those NGOs with positive answers, fund reduction comes as a result of the following reasons:

Table 4: Perceptions of Respondent NGOs of Reasons for Funding Change

\begin{tabular}{|l|c|c|}
\hline Statement & Frequency & Percentage \\
\hline Reduced aid (no explanation given by respondent) & 13 & $54.17 \%$ \\
\hline NGO proliferation in the oPt cause competitiveness over funding & 3 & $12.50 \%$ \\
\hline Funding shifted to Gaza humanitarian needs (2) and to Jericho (1) & 3 & $12.50 \%$ \\
\hline $\begin{array}{l}\text { Funding decreased as a result of the Palestinian internal divide, and World } \\
\text { Financial crises reduced fund available for foreign aid }\end{array}$ & 1 & $4.17 \%$ \\
\hline Donors frequently change approach to partnership with NGOs & 1 & $4.17 \%$ \\
\hline Donors funding shifted to PA & 1 & $4.17 \%$ \\
\hline Donors are biased in donations to some organizations & 1 & $4.17 \%$ \\
\hline Fund has increased & 1 & $4.17 \%$ \\
\hline Total NGOs Respondents & 24 & $100.00 \%$ \\
\hline
\end{tabular}

24 out of $40 \mathrm{NGOs}$ responded to this question. For each statement the percentage is derived from dividing the frequency over the number of total respondents (i.e. 24).

Secondly, since actual disbursement of foreign assistance to the oPt is way below the pledged amounts, the ability of Palestinian NGOs to receive and transfer funds has been limited in light of constant changes in donors' policies and regulations. In reality, NGOs do not have automatic, uninterrupted access to foreign funds but they have to go into lengthy processes before funding, usually conditional, is granted for a set of pre-approved interventions for a certain period of time. For instance, US funding is mostly disbursed through the US Consulate and USAID which have complex written guidelines and procedures for the provision and management of foreign aid. It has also been said that the input provided by the World Bank (EH, interview, 15 December; ER., interview, 15 December) and by the American envoy, Dennis Ross, are essential to the determination of priority sectors and strategies of foreign and USAID support to the oPt (Roys cited in Sbieh, 2011). Currently, USAID subjects its applicants and grantees to a host of vetting and oversight requirements, annual auditing, and legislative restrictions "because of congressional concerns that, among other things, funds might be diverted to Palestinian terrorist groups" (Zanotti, 2011, p. 1).

Thirdly, most funding is allocated to NGOs independent projects rather than support its organizational mandate and main program/services. The study revealed that $18 \mathrm{NGOs,} \mathrm{(about} \mathrm{45 \% )} \mathrm{depend} \mathrm{on} \mathrm{project-based} \mathrm{foreign} \mathrm{funding}$ compared to 22 NGOs that receive program support and depend on local resources. Probably the EU countries, unlike the US or the Arab donors, are the best known example of donors who provide multi-year financial support as a consortium rather than support independent projects, although there are signs that this policy is changing more towards project support (Costantini et al., 2010). The number of ongoing projects per organization can range between 3-6 projects, in order for the NGO to meet its running costs. It is very rare for an organization to receive support from various donors simultaneously, probably because of amount of labor-intensiveness required to meet the donors' reporting obligations on procurement, monitoring, evaluation, and strategic planning. 
Raed Awashreh

Table 5: Number of NGOs Donor-Funded Projects

\begin{tabular}{|l|c|c|}
\hline No of Ongoing Projects & Total & $\%$ \\
\hline Organizations with 1 - 3 donor funded projects & 13 & $54.2 \%$ \\
\hline Organizations with 4 - 6 donor funded projects & 6 & $25 \%$ \\
\hline Organizations with 7 - 10 donor funded projects & 4 & $16.6 \%$ \\
\hline Organizations with More than 10 donor funded projects & 1 & $4.2 \%$ \\
\hline Total NGOs with projects & 24 & $100 \%$ \\
\hline Organizations with Zero donor-funded projects & 16 & \\
\hline
\end{tabular}

Study sample: 40 NGOs in which 24 have donors fund projects, 18 are totally dependents on donors-funded projects, and 16 with zero donors funds projects.

Finally, the funding figures do not guarantee NGOs financial sustainability. On one hand, about $85 \%$ of surveyed NGOs, 34 out of 40 organizations, said they have not secured funding for the next few years while only 6 NGOs (about $15 \%$ ) said that their donors have promised future financial support. On the other hand, donors' funding allows for total or partial coverage of costs incurred by projects and activities they support. It is very rare to find a donor agency willing to invest in issues of long term sustainability of the NGO such as developing organizational assets, such as buildings, equipment and capital investment costs associated with services and income generation projects that relieve the NGO from reliance on support of their donors.

\subsection{WHO BENEFITS FROM FOREIGN AID}

Table 4 depicted the respondents' ideas on the factors behind the recent decline in foreign funding to the NGO sector. While it is difficult to come up with exact dollar estimates provided to the NGOs, it is even more difficult a task to track the exact beneficiaries of such funding. Even when studies attempt to do that, there are two main reasons to question the accuracy of their estimates. It is ultimately a matter of how researchers classify ${ }^{4}$ the NGOs and their activities. Very few organizations stick to one type of activity or social group to serve. For example, a women's NGO can be involved in a multitude of legal, economic, educational, health, outreach and other services benefiting not only women but their families, households and surrounding communities. More importantly is that NGOs usually track their own expenditures in terms of expenditure type rather than target groups. Unless the NGO is a very specialized organisation, it is almost impossible for them to provide researchers with accurate figures ${ }^{5}$ on the actual scope and impact of their activities.

Having said that, one should take NGO statistics and averages with a grain of salt. They are better looked at as indicative of funding trends rather than the value of exact support. For this reason, Figure 5.1 depicts the averages provided by two research studies on NGO funding in post-Oslo period and the 13 years span between 1995 up to the end of 2008.

The historical funding trend shows that health and education were the two sectors hit with substantial shrinking in donor assistance. For example, health received in 2008 half the amount it received in the previous decade with a drop from $42 \%$ to $19.6 \%$ of total NGO funding. Education also suffered a deeper decline, from $23 \%$ to just about $3 \%$ of total NGO funding, in the same years. This reduction may be explained partly by the fact that most important donors include health and education support in the direct bilateral assistance to the PA, which took over the responsibility of administering both sectors directly after Oslo. It should not be understood that both sectors developed to the point of not needing substantial donor support. In fact, there are many signs of the exact opposite, like long periods of general strikes in both sectors and deteriorating services to suggest such kind of improvement.

\footnotetext{
${ }^{4}$ For example, no NGOs present itself as 'infrastructure' organization. Public infrastructure is the responsibility of national and local authorities, not NGOs. Besides, infrastructure is included in every other subsector in MAS classification. For example a youth club or a health organization will build facilities but they are still considered service facilities rather than infrastructure per se. It is also notable that MAS methodology leaves out important sectors such as environment, agriculture, water, credit, housing, think tanks and research canters.

${ }^{5}$ To make statistics even less rigorous is that project expenditures often have hidden elements that cannot be seen unless the researchers study the budget and expenditures of each individual project. The amount of funding that eventually funnels down to the beneficiaries is usually a very small percentage of what is reported as total expenditures that also include administrative, operational and transactional costs. Donors also include the costs of their staff, experts, travel, contractors' profit, etc. in the figures they provide as the total value of foreign assistance provided to a specific organization and/or sector.
}

International Journal of Research -GRANTHAALAYAH 
In contradiction to the funding decline for health and education, some sectors had in 2008 received double the funding amount obtained in 1999. For example, funding for social services increased from $10.3 \%$ to $18.4 \%$ while human rights sector increased from $5.7 \%$ to $8.4 \%$ and youth increased from $1.6 \%$ to $4.0 \%$. The share of women's organizations, by contrast, dropped from $7.7 \%$ in 1999 to a mere $3.2 \%$ in 2008.

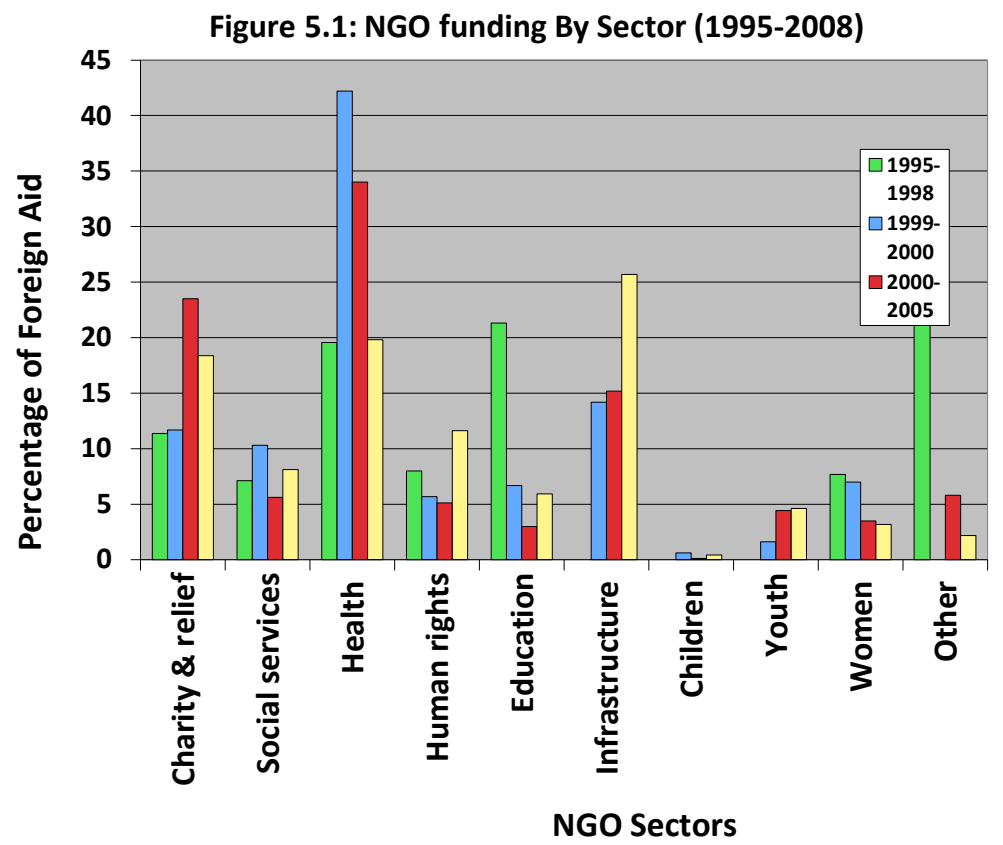

The table covers four periods for each sector except few covers three periods as the data is not available from its original source.

Source: Averages for 1995-1998 figures are provided by Hanafi (1999) Averages for 1999-2008 are provided by Devoir \& Tartir (2009)

Devoir and Tartir (2009) explain that this reduction in social services and women sector is the results of donors' desire to handover this responsibility to the PA while encouraging NGOs to focus more on advocacy and policy dialogue. In other words donors think that public policy, rather than service delivery, is the appropriate role for the NGOs to play in the Palestinian context. Similarly there was increase in infrastructure funding at the time of Israel's policy of uni-lateral disengagement from the Palestinians, including withdrawal from the Gaza Strip and the building of the Separation Wall in the West Bank. The funding enabled the opening of roads to serve Israeli settlers bypassing the Palestinian communities and road networks. As for the growing importance of human rights and youth funding after the Intifada II, some believe it aimed to distract the youth from political engagement and encourage them seeking their individual rather than the collective rights.

The above section concludes that Israel benefits directly from foreign funds allocated to the Palestinians and donors' attention always is to protect the state of Israel, its security and political concerns. For the past ten years, donors have also targeted youth believed to be the main actors in the Palestinian struggle against occupation and the main revolutionary forces since 1930s (Qassoum, 2004). For example, the USAID funds major youth programs to help them build their leadership skills and potentials as future leaders and promote conflict resolution, nonviolence, and entrepreneurship among the youth. M.B. expresses deep concern over USAID involvement with Palestinian youth, especially with the "youth shadow local councils" initiative that would create a loyal network of youth supportive of US interests in the West Bank (M.B., interview, $30 \mathrm{March}$ ). Some CBOs leaders share this sentiment as they see the youth shifting interests form the national to the liberal, and from community voluntarism to sport, art and other co-ed activities (MR., interview, 10 May).

These changing trends in certain sub-sectors can be read to either support or refute claims of donor funding drastically changing to support non-Palestinian priorities. There is a claim that donors push hard Western agendas with on women, youth and human rights NGOs but the percentage of their funding hardly shows such an 
overemphasis. The three sub-sectors combined received less than $15 \%$ of total 2008 funding when donors were preoccupied with stabilizing the PA after Hamas election win.

Quite the contrary, the finding seems to lend support to donor claims that their programs reflect the actual needs in the oPt, whether or not they support the Israeli agendas. If these percentages are indeed accurate and reliable, and that readers take objective analytical perspectives, the data contradicts much of the arguments about using NGOs to spread a neo-liberal agenda and the claim about the proliferation in the number of women, youth and human rights NGOs. If both claims are true, how come those NGOs survived the funding decrease? They do prove however, that funding is used to mitigate the harmful measures of the Israeli occupation in or against the oPt. For example, an analysis on donor funding between 2000-2005 shows that NGOs and donors prioritized relief, infrastructure, health and education at the time when Israel had militarily hit hard on the PA and enforced the most damaging economic siege on the oPt during the Second Intifada. The trend reappeared after the Israeli 2008 war on Gaza and the subsequent ongoing siege on the Gaza Strip. If anything, the figures seem to say that NGOs and their donors react or respond to humanitarian and relief situations in the oPt. This is the typical and historical mandate of most Palestinian organizations. How did both fare in their ability to meet the actual need, one has to go back and analyze the actual amount of relief funding received against the value of issued humanitarian appeals and cost estimates for building and reconstruction.

In this study, the survey has not asked respondent NGOs about the disaggregation of the size of funding and expenditures by subsector. From previous work, NGOs rarely disclose to researchers, or to the public, detailed information about their funding and financial resources. For this reasons, the survey inquired about finances in terms of organizational capacity asking for a total, rather than detailed, estimate of NGOs budgets, expenditures and assets in the last two years only. It was noticeable that 33 organizations answered that section while 7 NGOs declined maybe because individual respondents do not have knowledge of the financial affairs of their NGOs or because of their reluctance to disclose financial information.

The results are provided in Table 6 which clearly shows that 17 NGOs (i.e. $42.5 \%$ of study sample) have less than $\$ 100,000$ of annual revenues. About $50 \%$ of the same organizations have less than $\$ 100,000$ in total assets. 9 NGOs have revenues and 5 NGOs own assets valued between $\$ 100,000$ and half a million. Five NGOs generate more than one million in revenues annually while four have total assets worth more than 1 million 2010. These are the NGOs currently functioning through 5 or more donor-funded projects. This is indicative of the small size of most NGOs and funding programs generally in addition to NGOs weak financial sustainability potentials and ability to attract substantial funding. It is also indicative of the weak potential of NGOs to have any lasting impact through their project-based, small-scale intermittent activities or services. The 7 NGOs with revenues exceeding half a million may generate such amount not from local resources or service delivery fees but more likely to have received multi-year program support from one donor or received support from a consortium of donors. For example of a block of several Scandinavian countries supporting human and citizens right organizations that categorically decline US funding.

Table 6: NGO Financial Capacities

\begin{tabular}{|c|c|c|c|c|c|c|}
\hline \multirow{2}{*}{ Range } & \multicolumn{2}{|c|}{ Revenues } & \multicolumn{2}{c|}{ Fixed Assets } & \multicolumn{2}{c|}{ Total Assets } \\
\cline { 2 - 7 } & 2010 & 2009 & 2010 & 2009 & 2010 & 2009 \\
\hline$\$ 10,000$ or less & 4 & 4 & 13 & 12 & 8 & 9 \\
\hline$\$ 10,000-\$ 39,000$ & 10 & 10 & 10 & 11 & 11 & 10 \\
\hline$\$ 40,000-\$ 60,000$ & 2 & 1 & 2 & 1 & 1 & 1 \\
\hline$\$ 61,000-\$ 99,000$ & 1 & 1 & - & 1 & 2 & 1 \\
\hline$\$ 100,000-\$ 150,000$ & 4 & 3 & 3 & 3 & 3 & 3 \\
\hline$\$ 151,000-\$ 500,000$ & 5 & 7 & 3 & 3 & 2 & 2 \\
\hline$\$ 0.5-\$ 1$ million & 2 & 3 & 1 & 1 & 2 & 4 \\
\hline More than $\$ 1$ million & 5 & 4 & 1 & 1 & 4 & 3 \\
\hline Total organizations & 33 & 33 & 33 & 33 & 33 & 33 \\
\hline
\end{tabular}

Study sample: 40 NGOs, of which 33 responded to the survey financial questions.

Furthermore, this research showed that the higher capacity group of NGOs are created during the peace process era (1990-2000). About 5 organizations function with a budget of half a million dollar or more. By contrast, the most recent organizations, created after 2000, are the ones unluckiest in attracting huge amount of donor funding. For 
whatever reason, almost $42 \%$ of NGOs in the study sample operate with less $\$ 100,000$ a year. This entails that when overhead costs are subtracted from the meagre funds, organizations seem to be very local in coverage, operate through volunteers rather than hired staff, and/or provide activities or services at a small scale to leave a meaningful impact.

Table 7: No of Respondent NGOs Budget Size and Establishment Date

\begin{tabular}{|l|c|c|c|c|}
\hline \multirow{2}{*}{2010 Budget Size } & \multicolumn{3}{|c|}{ Establishment Date } & Total \\
& $\begin{array}{c}\text { Pre-Madrid Conference } \\
\text { (Before 1990) }\end{array}$ & $\begin{array}{c}\text { Peace Process era (1990 } \\
-2000)\end{array}$ & $\begin{array}{c}\text { After Intifada II (2001 - } \\
\text { Present) }\end{array}$ & 13 \\
\hline $\begin{array}{l}\text { Less than } \\
\$ 100,000\end{array}$ & 1 & 3 & 4 & 17 \\
\hline $\begin{array}{l}\$ 100,000- \\
\$ 500,000\end{array}$ & 1 & 4 & 0 & 9 \\
\hline $\begin{array}{l}\text { More than } \\
\$ 50,000\end{array}$ & 2 & 5 & 1 & 7 \\
\hline No answer & 5 & 1 & 18 & 7 \\
\hline Total & 9 & 13 & 40 \\
\hline
\end{tabular}

Table 8 shows that one third of NGOs are indeed of local CBO type functioning with less than $\$ 100,000$ per year at the district level, $25 \%$ or local level $42 \%$ compared to 13 organizations, less than one third, targeting the entire West Bank. As expected, the higher the budget, the more capacity the NGO have in covering a target area wider than its direct local community. In terms of beneficiary, the survey found no correlation between the NGO budget size and a beneficiary gender preference. It seems that disaggregation by gender is limited to the very local organizations that shy away from co-ed activities and lean more towards a specific gender. Usually, these are local organizations that are by mandate either dedicated to women or to young men although the majority of service organizations offer their services to the public regardless of the beneficiaries' gender.

Table 8: No of Respondent NGOs Budget Size, Area Coverage \& Gender Focus

\begin{tabular}{|l|c|c|c|c|c|c|c|}
\hline \multirow{2}{*}{2010 Budget Size } & \multirow{2}{*}{ Total NGOs } & \multicolumn{3}{|c|}{ Geographical Coverage } & \multicolumn{2}{c|}{ Gender of NGOs General Assembly Members } \\
\cline { 3 - 8 } & & West Bank & District & Local & Women & Men & Both \\
\hline Less than $\$ 100,000$ & 17 & 1 & 2 & 14 & 3 & 5 & 9 \\
\hline$\$ 100,000-\$ 500,000$ & 9 & 3 & 5 & 1 & 1 & 0 & 8 \\
\hline More than $\$ 500,000$ & 7 & 5 & 1 & 1 & 1 & 0 & 6 \\
\hline No Answer & 7 & 4 & 2 & 1 & 3 & 0 & 4 \\
\hline Total & 40 & 13 & 10 & 17 & 8 & 5 & 27 \\
\hline
\end{tabular}

Local coverage means an NGO operates in a single community (individual city, village or refugee camp).

Table 9 shows that most of study sample has consisted of small service delivery NGOs or CBOs equal to 35\% of the sample. Although they comprise a lesser percentage of the sample 8 out of 40 organizations (about 20\%) are advocacy NGOs receive larger funding and/or have larger budgets than service organizations. Only two advocacy and two service delivery organizations has 2010 budgets in excess of half a million compared to 3 NGOs with mixed mandate. This trend may in fact reveal donors' tendency to fund advocacy-focused NGOs or mixed-mandate ones through medium or large-value projects than fund service-only organizations whose activities/services are by default more specific and higher in costs that the advocacy only counterparts.

Table 9: No of respondent NGOs Budget size, Organization's Type \& Activities

\begin{tabular}{|l|c|c|c|c|c|c|}
\hline \multirow{2}{*}{2010 Budget Size } & \multirow{2}{*}{ Total NGOs } & \multicolumn{2}{|c|}{ Type of Organization } & \multicolumn{3}{c|}{ Type of Activities } \\
\cline { 3 - 7 } & & NGO & CBO & Advocacy & Service & Both \\
\hline Less than $\$ 100,000$ & 17 & 1 & 16 & 1 & 14 & 2 \\
\hline$\$ 100,000-\$ 500,000$ & 9 & 6 & 3 & 3 & 4 & 2 \\
\hline More than $\$ 500,000$ & 7 & 6 & 1 & 2 & 2 & 3 \\
\hline No Answer & 7 & 4 & 3 & 2 & 4 & 1 \\
\hline
\end{tabular}




\begin{tabular}{|l|l|l|l|l|l|l|}
\hline Total & 40 & 17 & 23 & 8 & 24 & 8 \\
\hline
\end{tabular}

Regardless of the exact sources or recipients of funding, i.e. PA or NGOs, Israel does benefit from foreign funding and any economic activities in the oPt. it was estimated that "for every dollar produced in the occupied territory, 45 cents flows to Israel. ${ }^{6}$ The remaining 55 cents is divided between expenditure on overcoming physical and administrative Israeli barriers and being spent on the project" (UN cited in PNGO Network Report, 2009, p. 33). The same applies on funding from the PLO, Arab or Palestinians sources because "PLO support fund eventually benefited Israel because of Palestinians' dependence on Israeli economy. For this reason, Israel allowed PLO funding into the West Bank and fought only the portion that aimed at promoting national struggle activities" (TB., interviews, 20 February).

The study also found that donors prefer supporting urban NGOs rather than CBOs and/or encourage NGOization in CBOs. About 50\% of the surveyed sample has accounting software available, and $38 \%$ to $43 \%$ has fully available written administrative and financial systems and about 10-25 of the sample has partially these systems. In addition, the investigation shows that organizations are more dependent on staff and less on volunteers.

Table 10: NGOs \& Size of Full-Time Staff and Volunteers

\begin{tabular}{|l|c|c|}
\hline \multirow{2}{*}{ No of persons } & \multicolumn{2}{|c|}{ No of NGOs } \\
\cline { 2 - 3 } & FT Employees & Volunteers \\
\hline Zero $*$ & 6 & 20 \\
\hline $1-5$ & 17 & 18 \\
\hline $6-10$ & 7 & 2 \\
\hline $11-25$ & 4 & 0 \\
\hline $26-50$ & 3 & 0 \\
\hline $50-100$ & 2 & 0 \\
\hline More than 100 & 1 & 0 \\
\hline Total NGOs & 40 & 40 \\
\hline
\end{tabular}

*The BoD manages the NGO directly when it lacks full-time employees or volunteers

Donor-dependent NGOs are more likely to become institutionalized in terms of developing formal structure, paid professional staff, and systems (financial, administrative, audit, etc.). These are a must in order for donors to consider large grants to any organization. Capacity building initiatives also encourage the consolidation of bureaucratic NGO features in grassroots organizations. ${ }^{7}$. The more the NGOs turn to hired staff, the more successful donors are in their 'co-optation' strategy to separate their leaders and professionals from the grassroots. Most leftist advocates of social justice, freedom, and equity are employed by INGO and urban-based NGOs promoting neo-liberal agenda (Qassoum, 2004) which turned them into careerists in the hunt for big salaries and more advanced career potentials in the oPt or beyond (A.B., interview, 2 March; Najem et. al, 2006). This professionalization and funding inflow have killed the spirit of voluntary work and turned activists into 'an army of staff' whose only "contribution to the national cause" is reporting to donors and advocating donor's approaches to development and empowerment of local communities (HN., interview, 17 March).

\subsection{NGO FUNDING AND PUBLIC PARTICIPATION}

As foreign funding to NGOs increased, the actual levels of public participation in NGOs have declined dramatically from the pre-Oslo years. As NGOs and donors' prioritized institutionalization, public participation lost its importance especially when community activists joined the rank of NGO management leaving a void difficult to

\footnotetext{
${ }^{6}$ Signs of economic dependency

${ }^{7}$ Examples: Palestinian Medical Relief Society (PMRS), Palestinian Agriculture Relief Committee (PARC), Health Work Committees (HWC) and many other organizations created by political parties as grassroots but became professionalized NGOs upon the availability of donor funding.
} 
Palestinian Perspectives on Foreign Aid

fill by international experts or INGO staff who could not substitute for the knowledge and relations of their local counterparts. Local NGOs and their managers turned their interest to fund-raising and higher salaries rather than to maintaining people's involvement with NGOs or make sure that their NGOs work according to people's needs (A.J., interview, 27 March; Sbieh, 2011). So, by turning the voluntary into a full time paid job, donors take the blame for seducing locals and killing the spirit of voluntary engagement among individuals and communities alike (KH., interview, 26 April; ES., interview, 5 January,; SA., interview, 1 February; HA., interview, 10 February; RN., interview, 25 April; ER., interview, 15 December).

For these reasons, researchers, academic and politicians, regardless of their affiliation and ideologies, equate 'grassroots' with 'high public participation' (Muhsin, 2010; Ashrawi, 2009; Hamamai, 2000; Jad, 2000). For Qassoum (2004) the grassroots or community organizations are 'democratic popular development movements' precisely due to mass public participation they allow. The public has not been oblivious to the shift in NGOs priorities and their declining engagement with the community to the point where they are reduced to service users (HI., interview, 9 April). The public is aware of NGOs foreign funding so they feel entitled to free NGO services and to paid employment instead of volunteering because NGOs receive money allocated to the Palestinian public. When the community notices signs of NGOs financial means (i.e. cars, fancy offices, frequent travel abroad), it become unfathomable to local residents to volunteer their time or dabble in poverty while NGO people are getting richer.

Presently NGO staffs are most probably kept very occupied writing proposals and reports to recruit more funds and respond to their donors' requests for paper work (HN., interview, 17 March). To obtain funding, NGOs have to pass a 'pre-award survey or capacity assessment' so the donor is insured its funds and projects are managed according to its liking (DW., interview, 23 April). Almost always, donors' decision to fund hinges on the availability of programmatic and management staff and systems at the potential recipient NGO (Sbieh, 2011). NGOs capacity is further measured not by the size of their beneficiaries or volunteers but by available funding and annual budgets (SA., interview, 1 February).

In addition to capacity assessment, strategic planning for NGO and PA ministries are largely controlled by foreign donors. The PA sectoral plans, Hamdan (2010) argues, often reflect Western criteria and judgments brought into the planning process through international consultants. For example, World Bank sets the guidelines for the use of its funding to PA and NGOs (EH., interview, 15 December; ER., interview, 15 December). It is also well known that the World Bank leads the PA economic and fiscal planning processes that emphasize the preparation of plan documents more than in involving the public in the process to ensure plans responsiveness to actual needs (Sbieh, 2011).

Donors' promotion of NGO advocacy over service delivery and relief (as advocated by Costantini et al., 2011) means that donors view PA as a permanent structure instead of being a transitional one limited to the duration of the peace process. What ensues is that service delivery has entirely become the responsibility of PA not NGOs and the PA becomes a permanent self-rule for Palestinians or semi-state at best, thus negating the need to continue struggle against occupation. Funding trends lend support to the above and NGOs themselves pointed out the funding decline to health and relief services while its increases for democracy, and governance, human rights, and peace promotion (Abu Ghoush cited in Hamdan, 2010: 31).

With a decline in or disappearance of foreign aid, it is difficult to tell how this will affect the relationship between the NGOs and the Palestinian public or how the NGOs themselves would survive under the scenario no foreign funding. However, absence of foreign aid will have a deep impact on people's lives in the short and long-term. People have to manage on their own resources for sure which is likely to revive people's interest in voluntarism and community work as was the case before 1990s.

\section{CONCLUSION}

Foreign aid to the oPt comes from the European states and other donors who prefer to work with more institutionalized Palestinian NGOs and occasionally CBOs. Foreign aid is a double-edged sword; it fuels the local economic but it also derails NGOs priorities, co-opts local elites, and de-politicizes grassroots. Thus, NGOs and political factions adopt the concept of 'don't throw the baby with the water bath' in suggesting that foreign aid should be managed differently but not rejected entirely. To influence foreign aid, NGOs need to build a united front and adopt a unified agenda instead of serving the personal interests of their leaders. 
While most Palestinian NGOs believe in the Palestinian national goals, the findings point out that NGOs sector believes that the PLO, PA and political parties, not NGOs, are responsible for their attainment. When NGOs are involved in advocating Palestinian national goals, they do so within the framework of PA's agendas and institutions, whether perceived as transitional or permanent self-rule structure. The dynamics of politics and foreign aid played a significant role in weakening NGOs adherence to national goals and public priorities. This is also true for politicallyaffiliated NGOs that take advantage of civil society arena as a substitute for direct and open engagement in politics and national struggle.

The findings show that less than one third of the surveyed NGOs actually work on top two priorities (poverty reduction and job creation) compared to less than $25 \%$ of NGOs responding to the third priority (education), and $10 \%$ focus on the fourth priority (health). Even when NGOs acknowledge the aforementioned public priorities, the surveyed NGOs could not agree on a set of priorities for the NGO sector because of their pre-occupation with shortterm material needs. NGOs fragmentation is not a sign of vibrant civil society but rather a sign of the sector's lack of a unified vision and real autonomy from foreign donors.

\section{SOURCES OF FUNDING}

None.

\section{CONFLICT OF INTEREST}

None.

\section{ACKNOWLEDGMENT}

None.

\section{REFERENCES}

[1] AbdulHadi, I. (2004). A broader vision of the role of Palestinian NGOs in the development process. Palestine: Bisan Centre for Research and Development.

[2] Abusrour, A. (2009). Palestinian civil society: a time for action. Retrieved from http://www.scribd.com/doc/16073466/Palestinian-Civil-Society-A-time-for-action-by-Amal-Abusrour.

[3] Al-Moaqat, F. (2007). The legal frame for organizing Palestinian NGOs work and its role in enhancing transparency and accountability. Palestine: Aman.

[4] Ashrawi, H. (2009). The case for democracy in the Palestinian national narrative.

[5] Retrieved from http://bakerinstitute.org/events/the-case-for-democracy-in-the-palestinian-nationalnarrative Costantini, G., Atamneh, J., Ayesh, Kh., \& Al-husseini F. (2011). Mapping study of civil society organisations in the occupied Palestinian territory. Retrieved from http://eeas.europa.eu/delegations/westbank/documents/news/20110712_ngomapping_en.pdf

[6] DeVoir, J., \& Tartir, A. (2009). Tracking external donor funding to Palestinian NGOs in the West Bank and Gaza 1999-2008. Retrieved November http://www.ndc.ps/uploads/File/Researches/Tracking\%20External\%20Donor\%20Funding.pdf.

[7] Hamdan, A. (2010). Foreign aid and the moulding of the Palestinian space.

[8] Palestine: Bisan Centre for Research and Development.

[9] Hamdan, S. (2010). Talk is Silver. Retrieved from http://www.palestine.rosalux.org/fileadmin/ab_palestine/pdf/RLF_newsletters_EN/RLF_PAL_Hamdan_Ta lk-is-silver.pdf

[10] Hamoudeh, D. (2010). The Zionist vision for the economy of the West Bank.

[11] Palestine: Bisan for Research and Development.

[12] Hamammi, R. (2000). Palestinian NGOs since Oslo- from NGO politics to social movements. Middle East Report, 214, 16-19+27+48. Retrieved from http://www.jstor.org/stable/1520188Accessed. 
[13] Hanafi, S. (1999). Profile of donor assistance to Palestinian NGOs: survey and preliminary findings. Retrieved from http://staff.aub.edu.lb/ sh41/dr_sarry_website/publications/145_Mazala.pdf

[14] Helpdesk Research Report. (2010). NGOs in the Palestinian Territories, Governance and Social Development. Reviewed from http://www.gsdrc.org/docs/open/HD707.pdf

[15] Jabber, F. (2011) Palestinian political parties: absent development vision. Retrieved from http://ar.bisan.org/sites/default/files/lhzb.pdf

[16] Jad, I. (2003). The NGOization of the Arab women's movements. Retrieved from http://www.siyanda.org/docs/jad_ngoization.doc

[17] Jad, I. (2007). NGOs: between buzzwords and social movements. Development in Practice, 17, 4-5.

[18] JMCC polling reports, Retrieved from http://www.jmcc.org

[19] Khaldi, K. (2008). Options for Palestinian state project. Retrieved from http://www.almashhed.com/t22049.html

[20] Kulick, A. (2007) International social welfare? Socioeconomic aspects of the economic crisis in the Palestinian Authority, strategic assessment. Retrieved from http://www.inss.org.il/publications.php?cat=21\&incat=\&read=16

[21] More, A. (2005) Killing with kindness: funding the demise of a Palestinian state, International Affairs 81. Retrieved from https://www.chathamhouse.org/publications/ia/archive/view/158703/inta81_5_981.pdf

[22] Najim, A. (1996). NGO Accountability: A Conceptual Framework. Development Policy Review, 14 (4) 339353.

[23] Nakhleh, Kh. (1989). Community organisations and social change- non- Governmental organisations and Palestine: the politics of money. Journal of Refugee Studies, 2, 113-124.

[24] Palestinian Central Bureau of Statistics. (2010). Issued child statistics, report on the eve of Palestinian $\begin{array}{llllll}\text { children's day } & \text { April } & 5, & 2010 . & \text { Retrieved }\end{array}$ http://www.pcbs.gov.ps/Portals/_pcbs/PressRelease/Kid_dayE_\%202010.pdf

[25] PJW- Palestine Journal Workshop. (2008). Seminar on NGO - Community Work, donations and foreign aids. [ Electronic version] Journal of Palestine Studies: 73 (19), 102-118. Retrieved from

[26] Palestinian Liberation Organisation. (1988). The Declaration of Independent Palestinian State. Retrieved November from http://www.jmcc.org/Documentsandmaps.aspx?id=766

[27] Qassoum, M. (2004). Local dialectic in the production and reproduction of the Palestinian space. [ PhD thesis]. USA: University of Illinois at Chicago.

[28] Samara, A. (2001). Epidemic of globalization: ventures in world order, Arab nation And Zionism. California: Palestine Research and Publishing Foundation.

[29] Sebieh, S. (2011). Problematic of Development Proponents: Between Mythical Application and Discourses' Dogmatic Illustration. Palestine: Bisan Centre for Research and Development.

[30] Zanotti, J. (2011). U.S. foreign aid to the Palestinians. Retrieved from http://fpc.state.gov/documents/organisation/166792.pdf.

[31] Zanotti, J. (2011). U.S. foreign aid to the Palestinians. Retrieved from http://www.fas.org/sgp/crs/mideast/RS22967.pdf accessed on Nov 29 